\title{
Technè
}

La science au service de l'histoire de l'art et de la préservation des biens culturels

45 | 2017

Bronzes grecs et romains : études récentes sur la statuaire antique

\section{The Name of the Artist, the Fame of the Bronze and the Bane of Multiples}

Le nom de l'artiste, la renommée du bronze et le fléau des copies

Carol C. Mattusch

\section{(2) OpenEdition \\ 1 Journals}

Electronic version

URL: http://journals.openedition.org/techne/1220

DOI: $10.4000 /$ techne. 1220

ISSN: 2534-5168

Publisher

C2RMF

\section{Printed version}

Date of publication: 1 May 2017

Number of pages: $14-23$

ISBN: 978-2-7118-6408-9

ISSN: $1254-7867$

Electronic reference

Carol C. Mattusch, "The Name of the Artist, the Fame of the Bronze and the Bane of Multiples »,

Technè [Online], 45 | 2017, Online since 19 December 2019, connection on 22 July 2020. URL : http:// journals.openedition.org/techne/1220 ; DOI : https://doi.org/10.4000/techne.1220

\section{(c) (i) $\odot$}

La revue Technè. La science au service de l'histoire de l'art et de la préservation des biens culturels est mise à disposition selon les termes de la Licence Creative Commons Attribution - Pas d'Utilisation

Commerciale - Pas de Modification 4.0 International. 


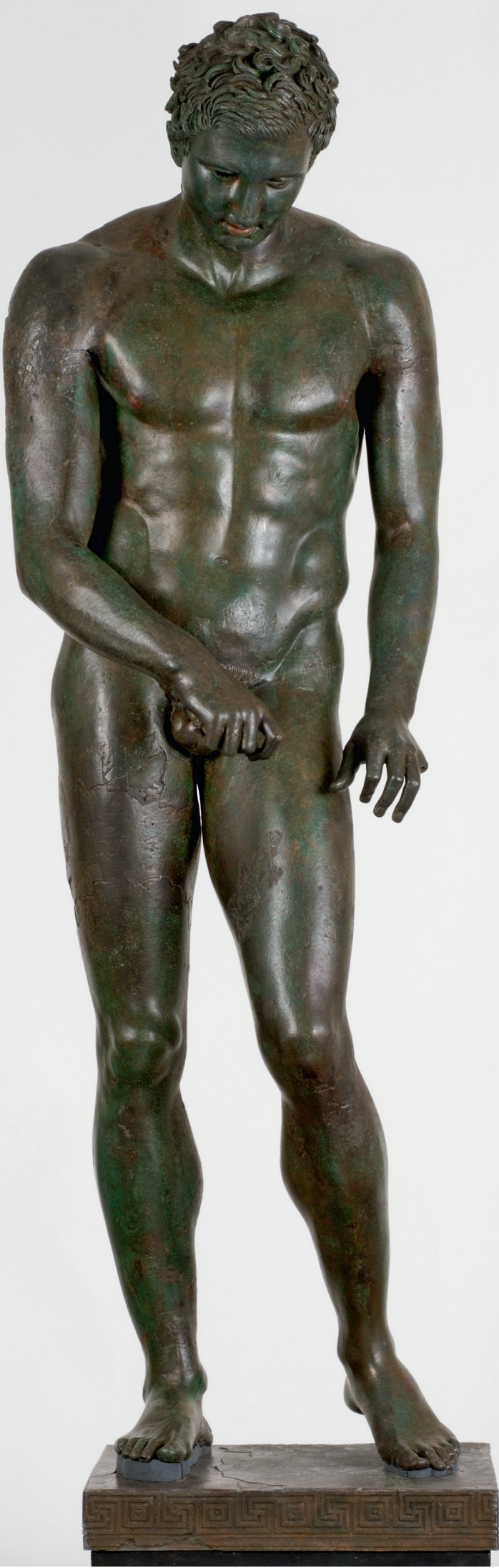

Fig. 1. Croatian Apoxyomenos, bronze, H. 192 cm, Republic of Croatia, Ministry of Culture. (c) L. Gamulin (Croatian Conservation Institute). 
Carol C. Mattusch The Name of the Artist, the Fame
of the Bronze and the Bane of Multiples

Le nom de l'artiste, la renommée du bronze et le fléau des copies

Abstract. The production of decorative bronzes in multiples was a long-standing tradition in the classical world, for small-scale works such as protomes for caldrons in the 7th century B.C., statuettes from the 6th century onwards, and fulcra for couches made in the Hellenistic and Roman periods. With the discovery of the Croatian Apoxyomenos, reproductive processes for large-scale statues can now be documented as well.

Keywords. Apoxyomenos, griffin, herm, Lysippos, multiples, Piombino, Praxiteles, Pseudo-Seneca, Riace Bronzes, Sauroktonos.
Résumé. La fabrication de bronzes décoratifs à plusieurs exemplaires était une tradition ancienne dans le monde antique, pour des cuvres de petit format comme les protomés de chaudrons au VII ${ }^{e}$ siècle avant J.-C., les statuettes à partir du VI $I^{e}$ siècle, et les appuis de banquettes aux époques hellénistique et romaine. La découverte de l'Apoxyomène de Croatie permet maintenant d'attester le recours à des procédés de reproduction pour des statues de grandes dimensions également.

Mots-clés. Apoxyomène, griffon, hermès, Lysippe, copies, Piombino, Praxitèle, Pseudo-Sénèque, bronzes de Riace, sauroctone.
Modern scholars have long considered large-scale classical bronzes to have been unique productions, only one having been produced to a single design, even though there are many small-scale bronzes that all would agree were produced in multiples, simply because they are decorative elements for such objects as vessel-handles and furniture-attachments. The problem with large bronzes is that very few of them have been discovered, and they have always been different - until recently.

\section{Lysippos}

The discovery of the Croatian Apoxyomenos in 1999 (fig. 1) led scholars to consult Pliny the Elder's Natural History, book 34 , in which he associates famous bronze statues with major Greek artists. Pliny reports that Lysippos, a bronze artist whose family-members were bronzeworkers, made 1500 works, most of which were apparently generic statues of athletes, but Pliny specifically cites portraits of Alexander the Great and statues and groups representing Alexander's friends and colleagues, a portrait of Sokrates, a tipsy flute-girl, a colossal Zeus, several statues of Herakles - both colossal and miniature, an Eros, Kairos (Opportunity), a Poseidon, and a destringens or Apoxyomenos (Natural History 34.62-64).

Modern scholars have identified some famous Greek bronzes in surviving marbles that appear to fit Pliny's descriptions, and of which there are often multiple examples, serving as an indication of their popularity. Usually, these marble sculptures are from Roman contexts. There are few surviving Greek or Roman bronze statues, owing to the value of bronze as a reusable material.

Pliny describes a typical bronze by Lysippos as having a small head, carefully modeled hair, and a slender body, which makes each statue look taller than it actually is. He also explains that these statues have symmetria, a Greek word for which no word exists in Latin, and whose meaning is debated by modern scholars. Furthermore, statues by Lysippos have a subtlety in the surface, particularly in the details, whereas, he goes on, other artists' statues are more quadrata, by which he evidently means more squared or more balanced (Natural History 34.65). These features ought to help us identify works that Lysippos designed, but they do not, because scholars' differing interpretations of this passage are difficult to reconcile.

By the latter part of the 1st century B.C., the famous bronze Apoxyomenos by Lysippos had been brought to Rome, and Pliny writes that Marcus Agrippa had it installed in front of his baths. But Tiberius (ruled 14-37 A.D.) was so infatuated with the statue that he had it moved to his palace and placed in his bedroom, substituting some other unnamed statue at the Baths of Agrippa. The people objected, demanding that the Apoxyomenos be returned to them, and Tiberius had to relinquish the statue (Natural History 34.62).

Gisela Richter observed: "A reproduction of this statue has long been recognized in the Apoxyomenos in the Vatican, 
for it seemed to bear out in a striking way the characteristics of Lysippos summed up by Pliny... But we can obtain no real conception of the beauty of the original from this indifferent marble copy ${ }^{1}$." The marble Vatican Apoxyomenos, arms outstretched horizontally, is so far the only one of its kind, which would be peculiar for a statue-type that was very well-known (fig. 2). If it is indeed the type that was introduced by Lysippos, about which the literary testimonia had so much to report, why are there no other copies of this statue?
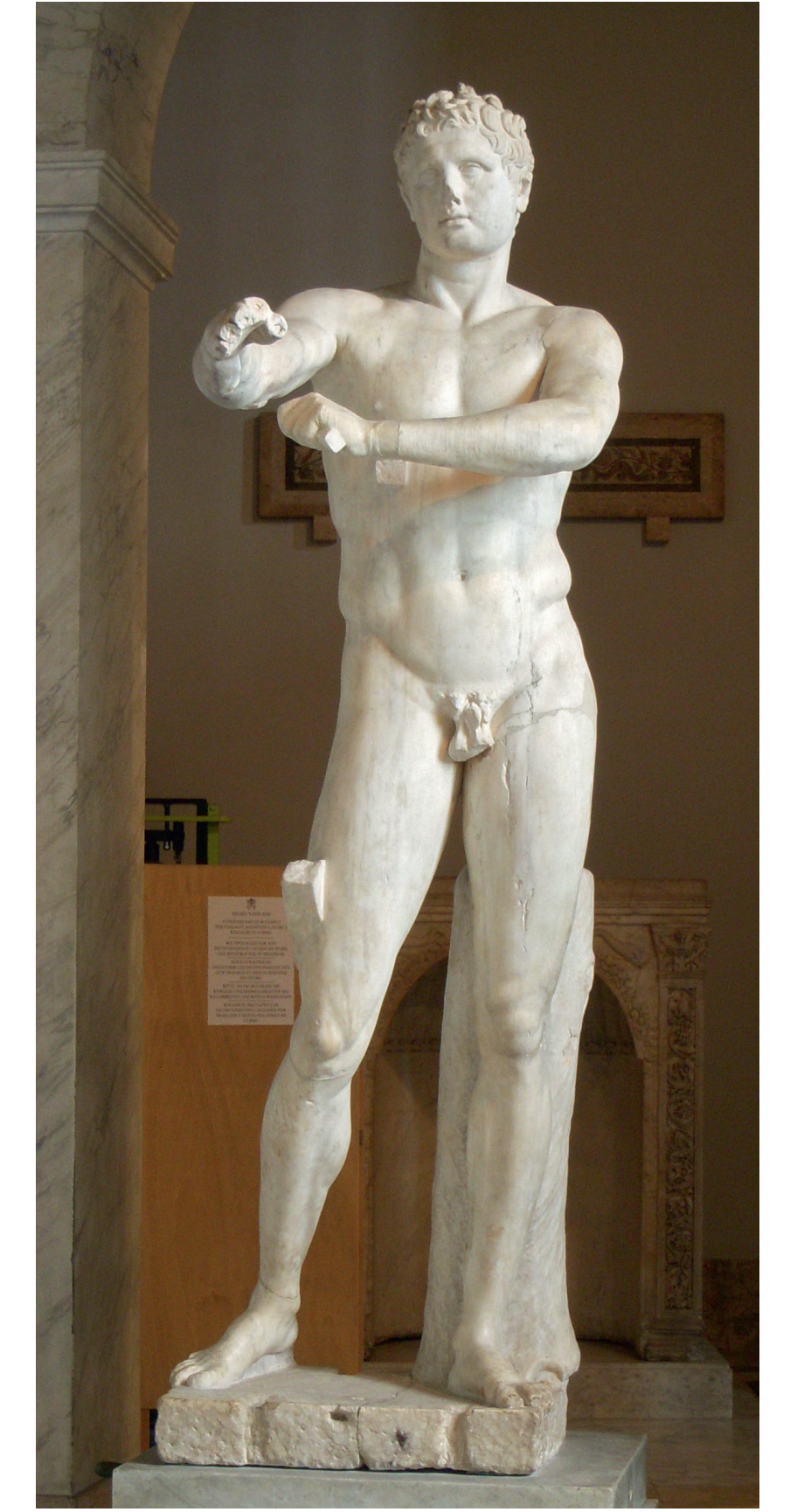

Fig. 2. Vatican Apoxyomenos, Museo Pio Clementino, marble, H. $205 \mathrm{~cm}$. (C) C. Mattusch.

\section{Griffins}

Nobody has ever denied that protomes were produced in multiples, since six or eight of them were normally attached to a single vessel. A careful look at how three huge seventhcentury-B.C. Orientalizing griffins' heads were made reveals that they were all produced in the same workshop, even though they are now housed in three different museums - Olympia, the National Archaeological Museum in Athens, and the Metropolitan Museum of Art in New York ${ }^{2}$. In fact, all were said to have come from Olympia, but on no specific grounds. Despite significant variation in their states of preservation, the three griffin-heads look similar, they are all about the same size ( 25 to $28 \mathrm{~cm}$ in height), and they were all originally attached to separate, probably hammered necks ${ }^{3}$. A close look proves that they were all made by the same process and worked over with the same tools.

It is not the lost wax process as it is practiced today. The models for the griffins consisted of matching pre-sized sets of wax slabs (fig. 3a, b). One formed the lower mandible; another the upper mandible. Two more slabs of wax attached vertically to the sides of the mandible were shaped into the head and joined at the crown. Holes were cut for the eyes. The griffins' tongues were made from wax strips, while squat knobs and slender upright ears were rolled and cut into shape. Two punches of different sizes were used to mark the scales on each wax griffin: a small one for the area below the eyes; and a larger one for the rest of the head. Each of the completed waxes was stabilized by the addition of a clay core, and then covered with a clay investment mold for casting.

Because each griffin was produced individually from a set of wax slabs, each bronze is a little different from the others. But there is no doubt that they were produced as a group in one workshop at Olympia. The tripod caldron to which they were attached was a major dedication of the second half of the 7th century B.C.: it stood between 4.6 and 5.6 meters in height, that is, between two and a half and more than three times the height of a $\operatorname{man}^{4}$. So far, there is no additional evidence for making multiples by using matching groups of wax slabs. Lacking no other protomes of this size, we must conclude that this was an experiment, and that the process was designed specifically to produce these remarkably large griffins for what was surely an unusual commission.

\section{The Bane of Multiples: Riace}

The production of multiples from one basic model became the norm during the 6th century B.C., to judge from statuettes that have come to light in duplicates ${ }^{5}$. When the two Riace Bronzes were found off the coast of Calabria in 1972, they gave rise to intense speculation about their identities and origins. Scholars most frequently asked which famous artists had made them, picking names and dates from Book 34 of Pliny the Elder's Natural History. Was it Onatas, Myron, Phidias, the school of Phidias, Polykleitos, or a follower of Polykleitos, 


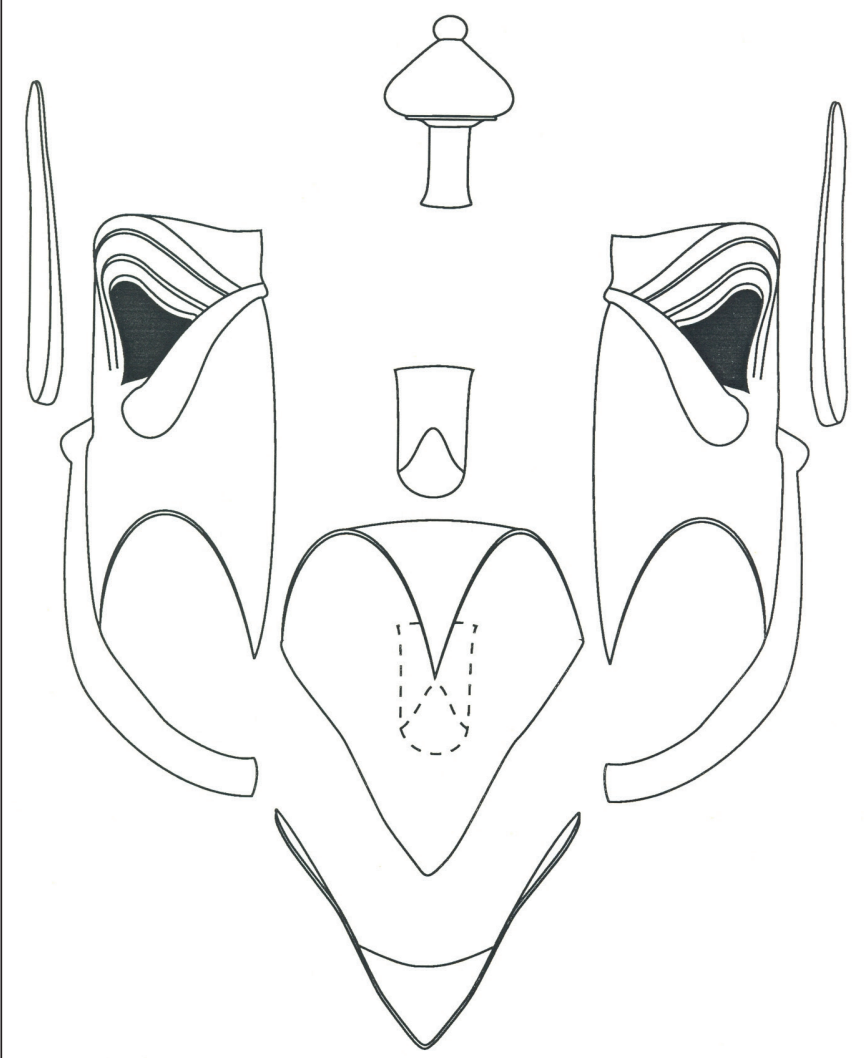

Fig. 3a. Computer-generated drawing of the wax slabs used to cast 3 large griffin protomes. From Carol C. Mattusch, "A Trio of Griffins from Olympia”, Hesperia 59, 1990: 549-60, pl. 91d. (C) Drawing by Avrim Katzman.

or were the two statues perhaps made by different artists? Another commonly asked question was whether they represented heroes, or generals, or hoplitodromoi. Dates assigned to the two statues ranged from 460 to 450 , or from 450 to 440 , or to sometime between 100 B.C. and the reign of Hadrian in the 2nd century A.D. Some scholars believed that Statue A was made before 460, others preferred the decade between 460 and 450; Statue B, some argued, was made after 450 , and others placed its manufacture between 440 and 430 B.C. Arguments were made for their having come from Athens, Olympia, Delphi or a South Italian city. Could they have been seen by Pausanias? The arguments were stylistic, bolstered by what the encyclopedist Pliny had to say from his first-century-A.D. perspective about bronzes that he also viewed as ancient works ${ }^{6}$.

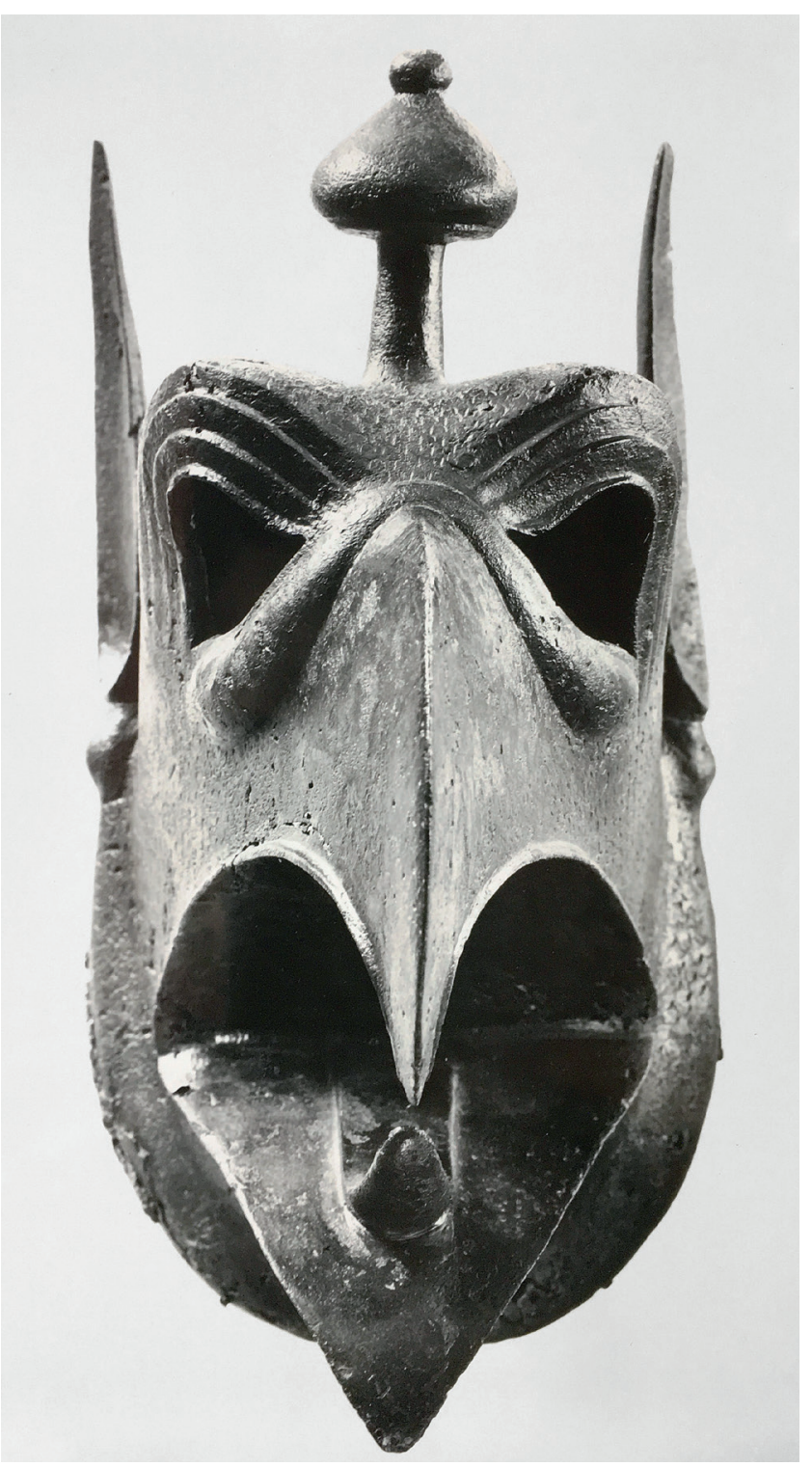

Fig. 3b. Head of griffin from Olympia, Olympia Museum, B 145 and B 4315, bronze, preserved H. 27.8 cm. (C) D-DAI-ATH-Olympia 4963/E.M. Czakó.

Non-specialists looking at the Riace Bronzes tend to respond differently to the statues than do art historians, often noticing their similarities instead of their differences. The observations of non-specialists are in accord with some of the objective evidence derived from technical studies that were conducted on the statues. The measurements of Riace A and $\mathrm{B}$ match very closely, and the two statues have virtually identical profiles, contours, gestures and poses, though the feet of Statue A are slightly farther apart than the feet of Statue B. As Edilberto Formigli first argued, the evidence shows that both statues were derived from molds taken from the same basic model. They were individualized in the wax workingmodels, at which time the feet were positioned, surface modeling was enhanced, and curls for the hair and beards were designed and added in wax ${ }^{7}$. Vinzenz Brinkmann's 
illustrations demonstrating his recent hypotheses about the Riace Bronzes reveal how colors and accessories might have been used to create variations between these two statues that were cast from the same basic model $^{8}$, but these are theories that provide no definitive answers to the questions.

The Riace Bronzes are what might best be described as two editions of the same model, different enough to represent two individuals, but close enough in size and pose that they could have been placed on a single base as part of the same monument, if that were required. They could have been produced by different artisans in different workshops, or not. This interpretation did not sit well with those scholars who believed that Greek bronzes were produced as individual works and were not repeated. And the modern construction of chronology on the basis of style is also on shaky ground when we consider that a style, once introduced, lasted for as long as it was popular with buyers. Surely different workshops offered models of the same images, as was the case with marbles.

\section{Two bronze herms, and a marble one}

A herm of a turbaned Dionysos from the early first-centuryB.C. Mahdia shipwreck matches a bronze herm in the Getty Museum (fig. 4-5), which was at first dismissed as an ancient replica of the Mahdia herm but of lesser quality, or as a modern forgery ${ }^{9}$. Their measurements are the same. The Mahdia herm's surface is degraded by years in the sea, whereas the features of the Getty herm are still sharply defined, but one can see that they were not as carefully finished. It is a thin and even-walled casting, because little or no work was done on the wax before casting. The Mahdia head is thicker in some places than in others, because it was carefully detailed in the wax. A wreath was entwined with a more elaborate turban, and long corkscrew side-locks were added in front and in back. One additional feature on the Mahdia herm is a barely visible dotted inscription on the right boss reading: "Boëthos of Kalchedon made it." The Getty herm has no inscription, but its left boss is missing, which may or may not have been inscribed.

Each herm was cast from a wax working-model that consisted of a head attached to a shaft made of joined rectangular slabs. On the Getty herm, those slabs were stabilized by vertical rods, one on the interior of each side of the shaft. The rods, probably sticks, burned out during casting. The two herms have the same basic alloy, each one containing a little cobalt, an unusual trace element for them to share. It is the cobalt - not the major components (Getty herm: ca. 70\% copper, $17 \%$ lead; $13 \%$ tin; Mahdia herm: ca. $71 \%$ copper, $18 \%$ lead, $10.3 \%$ tin) that makes it likely that the two herms were cast from a single batch of metal in the same workshop, perhaps even during the lifetime of Boethos in the 2nd century B.C. But why is one herm so much more carefully produced than the other? Perhaps Boethos signed the wax that he himself had worked on, leaving another wax for technicians to cast

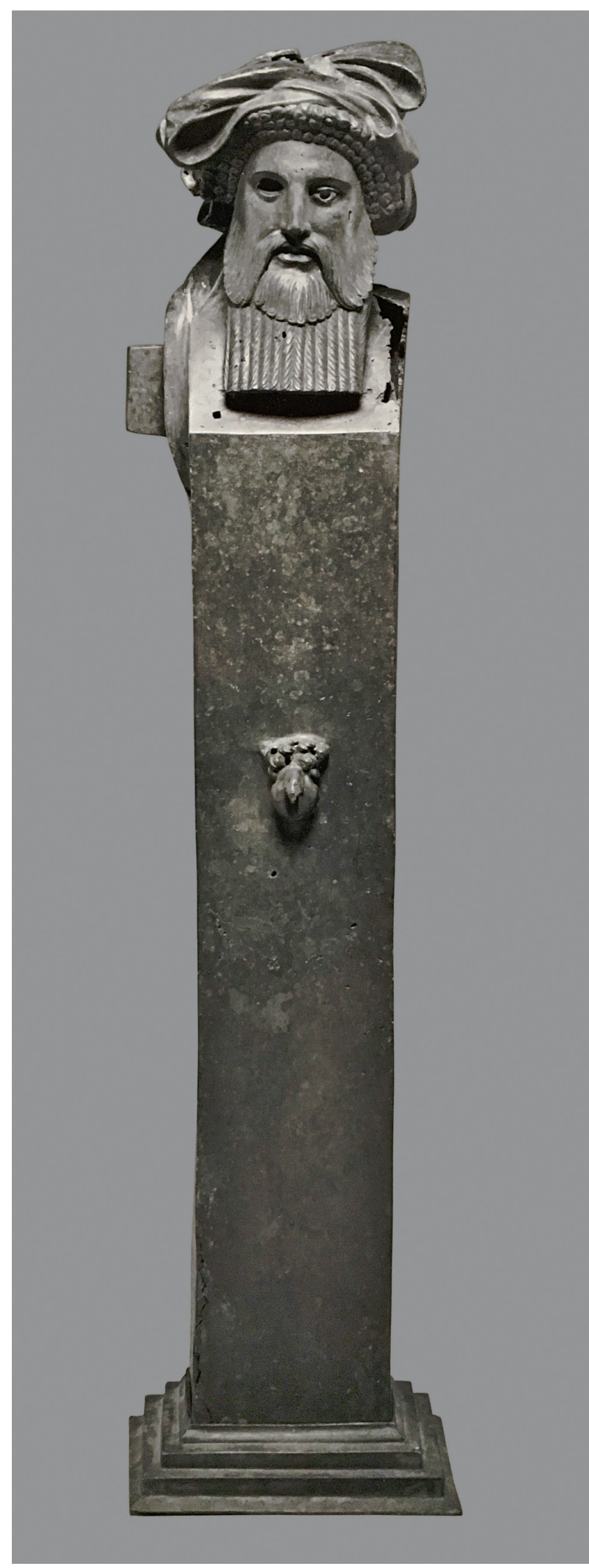

Fig. 4. Herm of Dionysos, bronze, Los Angeles, J. Paul Getty Museum acc. 79.AB.138, H. $103 \mathrm{~cm}$ (without base). (c) Courtesy J. Paul Getty Museum. 


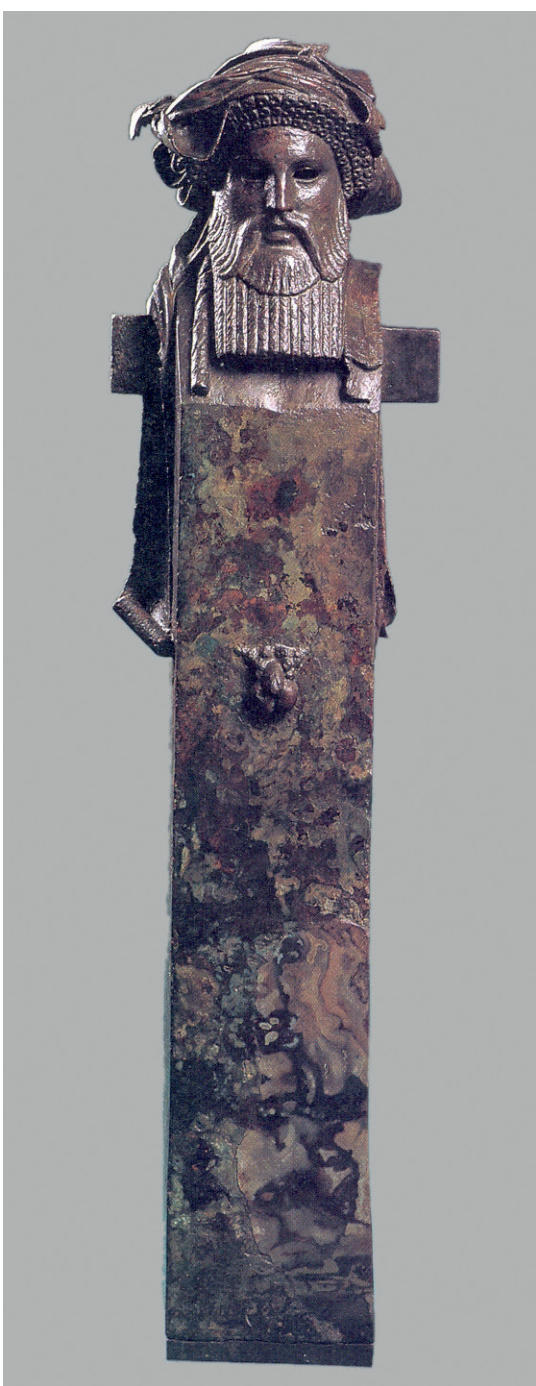

Fig. 5. Herm of Dionysos from the Mahdia shipwreck, inscribed by Boëthos as maker, late 2nd century - ca. 70 B.C., bronze,

H. $103 \mathrm{~cm}$, Tunis, Bardo Museum, inv. F 107.

(C) Photo courtesy Rheinischen

Landesmuseum Bonn, by H. Lilienthal.

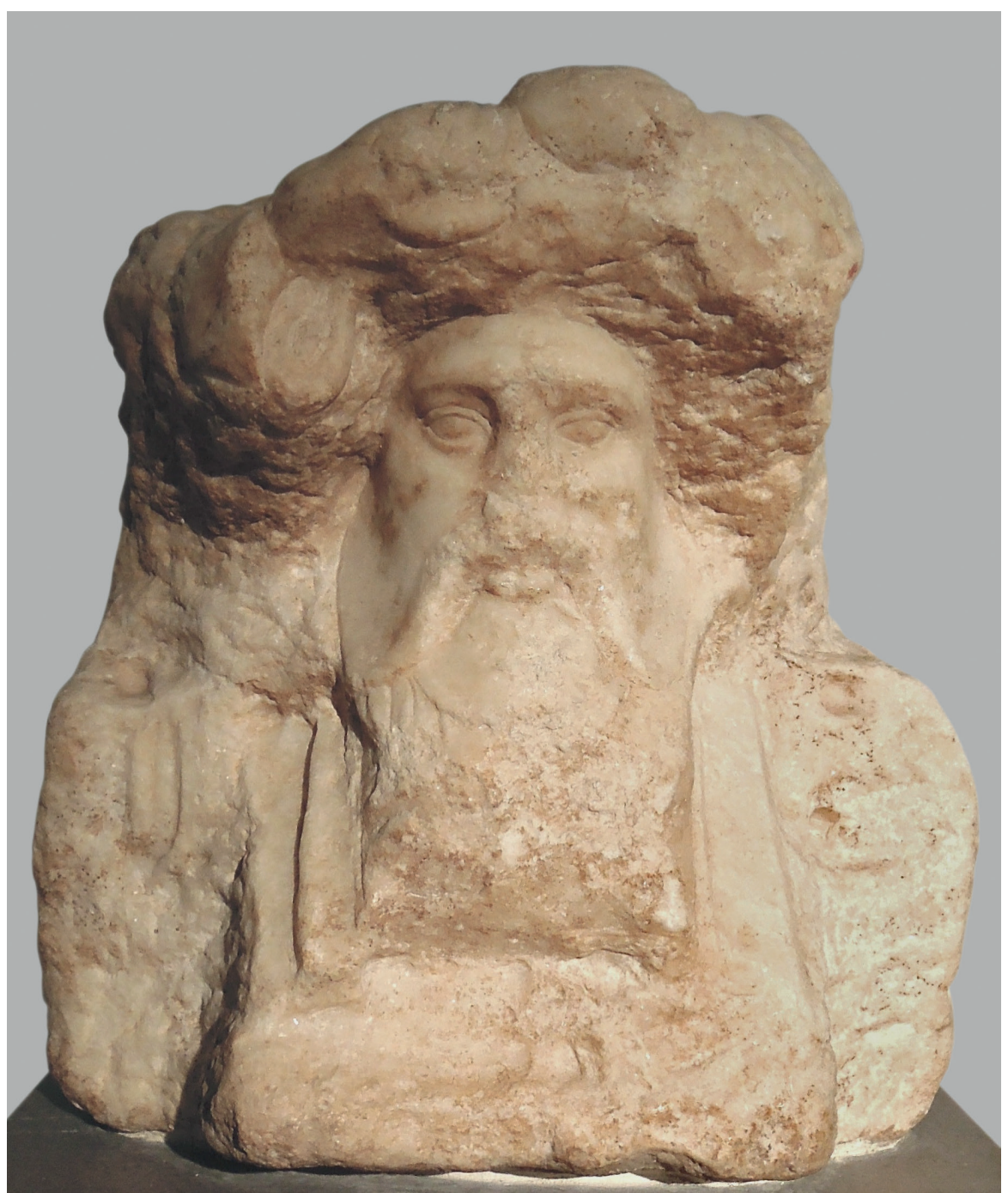

Fig. 6. Unfinished herm of Dionysos from South City Wall at Aphrodisias, 1st century A.D., white marble, H. 35 cm, Aphrodisias Museum M.S.1.yy. () Photo courtesy of Kenneth Lapatin. just as it came out of the master molds to a less discerning client.

Many versions of the turbaned Dionysos have turned up throughout the classical world; they have been dated from the 2nd century B.C. onwards. There are terracottas, marbles, gems and reliefs. But only one example very closely matches the two bronze herms: an unfinished marble herm found built into a first-century-A.D. wall at Aphrodisias, in Turkey (fig. 6). The resemblance is startling, and the appearance of this unfinished work in Aphrodisias, known for its production of marble sculptures, is proof of the dissemination of models from one workshop to another, or of an artist's release of his specific design to workshops producing works in different media.

\section{Piombino Apollo and Pompeii Apollo}

Scholars once thought that the bronze statue from Piombino was Archaic or shortly post-Archaic, but they could not agree (fig. 7). When they looked at the lead tablets inside, they read that it was made by two Rhodians (either in Rhodes or in Italy) between the late 2nd century and the early 1st century B.C. New investigations of the statue have since been undertaken; and careful study of the lead tablets has narrowed down a date for the Piombino Apollo to the last quarter of the 2nd century B.C ${ }^{10}$. In 1977, a similar statue was found in Pompeii in 1977. That one too stands in the stiff frontal position of a traditional Archaic Greek kouros, except that they found a tray that he held on his outstretched $\operatorname{arms}^{11}$. To look 


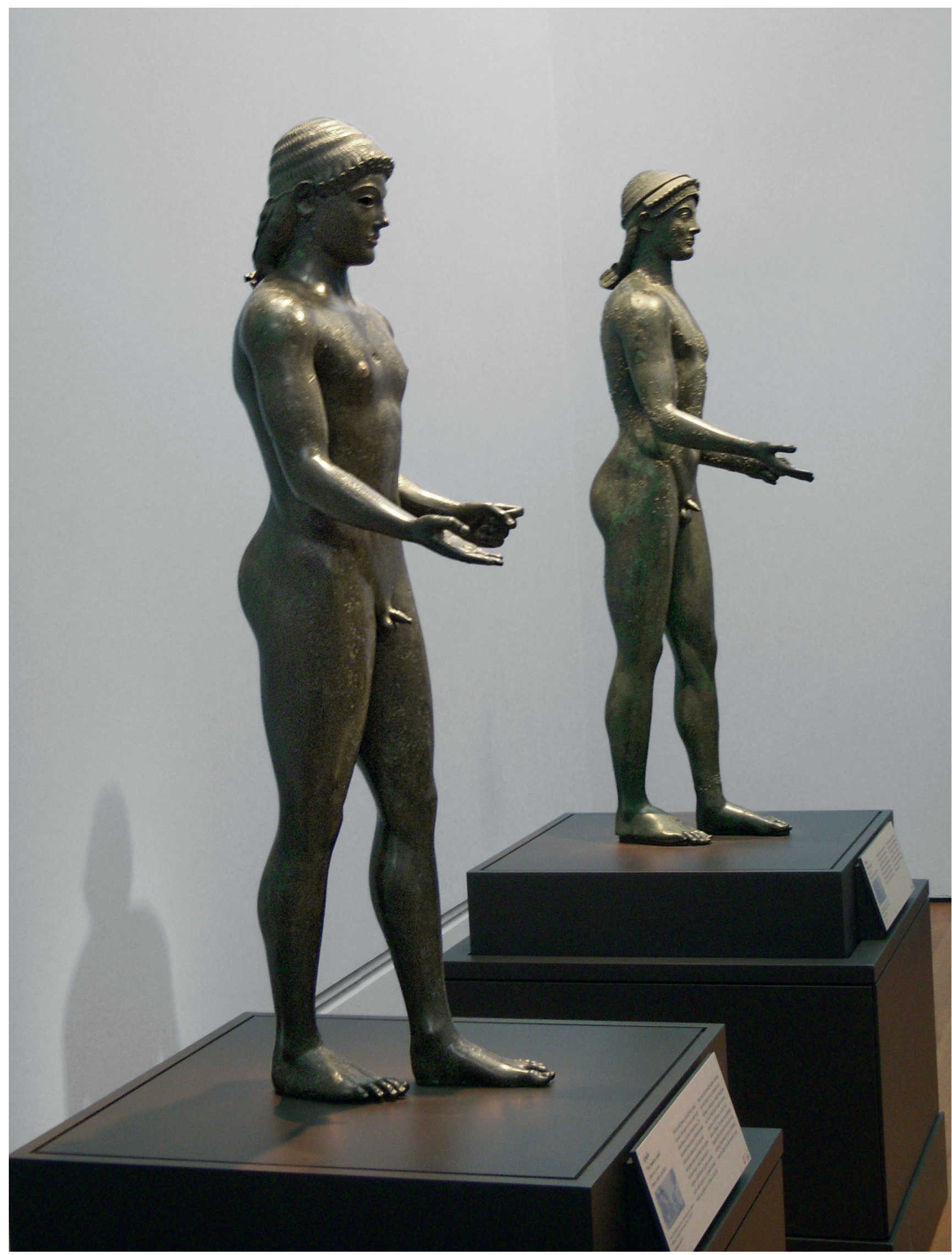

Fig. 7. Piombino Apollo, bronze, Paris, musée du Louvre, inv. Br. 2, H. 117 cm; Pompeii Apollo, bronze, Paris, musée du Louvre, inv. no. 22924, H. 128 cm. @ Photo courtesy of Kenneth Lapatin. 
at the two statues, we see that the basic model is the same; the differences are in superficial details, such as in the rendering of the hair and of the diadems. These individualizing features were added to the wax working-models, and the two bronzes are two editions of the same basic original model, showing the Hellenistic and Roman attraction to an archaizing Greek type. The measurements are quite different as well, perhaps suggesting the use of drawings as models, and possibly also production in two different workshops ${ }^{12}$. One statue found its home in Pompeii, where it may have been produced, whereas the other was being sent to a different location when it was jettisoned or the cargo-ship went down.

\section{Pseudo-Seneca}

There are more than forty surviving examples of the portraithead of a wizened old man with unkempt hair; all but one of them are carved in marble ${ }^{13}$. All were evidently produced during the Roman period and most if not all were attached to herm-posts. The only surviving bronze version comes from the Villa dei Papiri at Herculaneum (fig. 8) ${ }^{14}$, whose owners, like the Greeks, clearly preferred bronzes over the marbles, in contrast to the usual Roman preference for marble. At what point the head was acquired for that villa's collection is unknown. The objects in the collection were oriented towards Greece: only three portraits of Romans can be identified among the 65 bronzes from the villa, and three Roman portrait-statues among the 22 marbles.

None of the heads has the name inscribed, and we do not yet know which important individual is represented, despite this portrait's widespread popularity among the Romans. Johann Joachim Winckelmann called the old man Seneca, the name that had been applied in the late 16th century when the first example was found. Since then, scholars have identified the portrait-type as Aesop, Hesiod, Euripides, Aristophanes, Eratosthenes of Cyrene, Piso, Lucretius, or Philemon. Given the lack of consensus, today the portrait is usually named simply the Pseudo-Seneca, one of the few Roman identities that have been applied to the head.

Six heads of this man whom we do not know were found around the Bay of Naples; the one from the Villa dei Papiri is the best-known of all the heads, if only because it is made of bronze. Its material, which is so rare today, has led more than one scholar to refer to it as the best example of its type or even as the original from which all the marbles were copied. The study of ancient bronzes is no longer a purely art historical endeavor, however, and technical features of the bronze head reveal a different story. This Pseudo-Seneca is a thin even casting, a simple indirect lost-wax reproduction of its wax model. It does, however, display a few signs of careless workmanship: the forehead between the two central locks of hair is at a higher level than the rest of the forehead; there is a crudely finished repair in the lower right side of the forehead; and a curl is not clearly distinguished from the helix of the left ear. These features show that the details were not corrected

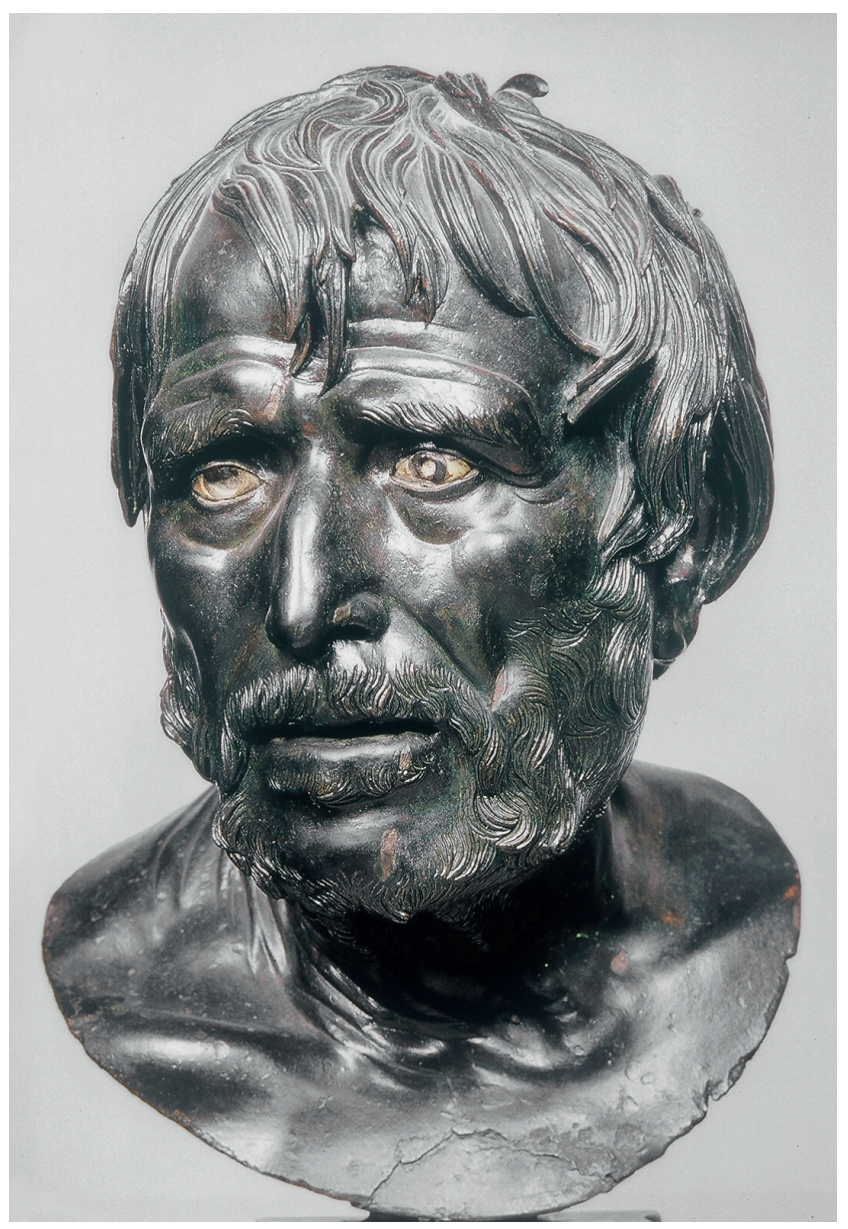

Fig. 8. Head of Pseudo-Seneca, bronze, H. 33 cm, Naples National Archaeological Museum, inv. no. 5616. (C) Digital image courtesy of the Getty's Open Content Program.

or finished in the wax before casting, but that the head was cast just as it came out of the molds. Thus it appears to be an example of a rapidly produced version of a popular type; but it happens to be the only surviving example that was cast in bronze. The term "original" does not apply.

\section{Praxiteles and the Sauroktonos}

Two bronze statues and a number of marbles represent a very young Apollo leaning on a tree, about to strike a lizard with a rock. Clearly it was a widely known statue in antiquity, and no doubt it made an excellent garden ornament. There is a small bronze version in the Albani collection in Rome ${ }^{15}$, and a larger bronze version is now in Cleveland. The latter is a thin even casting, with little or no evidence that any details were added to individualize the work in the wax workingmodel before casting. There is no way to know whether the bronze in Cleveland was the first bronze made after the model designed by Praxiteles ${ }^{16}$, whose works are better known today 
through marbles. Once a statue or a type existed, it could be repeated whenever there were buyers, and the buyer was - and still is - the one to choose the medium, whether a model by Praxiteles or one by Auguste Rodin. It is to the artist's advantage to secure more than one buyer for a bronze taken from a particular model, because the more bronzes that are cast at one time, in a single edition, the lower the cost of production. Copies of a single three-dimensional model could be much more alike in measurements and details than those derived from two-dimensional models, and might also signify closer control over the finished versions by the artist who produced the model. If there were no intentional changes from the model, a series could be mass-produced, resulting in lesser cost of production and greater income for both the foundry and the designer.

\section{Lysippos and the Other Apoxyomenos}

Neither G. Richter nor P. Moreno mentions that there is another type of Apoxyomenos besides the marble statue in the Vatican ${ }^{17}$. But a full-size bronze statue with a scraper had been found in the Harbor Baths Gymnasium at Ephesos in $1896^{18}$ (see in this volume fig. 1 in G. Plattner's article). Since a second bronze one was pulled from the sea off the coast of Croatia near the island of Losinj in 1999 (fig. 1), the notion of a "Greek bronze original" has lost most of its remaining adherents ${ }^{19}$. There are several marble sculptures of the same type, a basanite example, and a few heads without bodies, including a bronze head in the Kimbell Art Museum, Fort
Worth, Texas ${ }^{20}$. These numbers indicate that the statue was a popular and well-known type.

With respect to their production, all three bronze heads, Vienna, Croatia and Kimbell, were joined to the neck at the same angle, beneath the jaw and across the nape of the neck. All three heads are inclined forwards; they all have the conventional puffy ears of athletes; and they all wear the same distinctively swirling tight curls, short and bristly around the face, with thicker ringlets on the crown of the head. Some of the strands of hair and projecting curls of the bronzes were hand-carved in the wax working-models, resulting in three slightly different editions of the same basic model.

The notion that any Greek bronze was an "original" drove the discussion of the Riace bronzes, the focus being on identifying the differences between them rather than on finding their many similarities. The discovery of the Croatian Apoxyomenos contributes much to the recognition that popular statues were reproduced in multiple castings and "editions". This is how Lysippos was able to make so many statues, and this is how he advanced the art of sculpture (Pliny, Natural History 34.65). At the same time, it is unprecedented to have three bronze examples of the same bronze, in addition to marble versions of the same statue. We can conclude that they are all likely to represent the Apoxyomenos designed by Lysippos. And we can now begin to see that the production of multiples in bronze was a longstanding tradition in the ancient world. Consideration of the surviving multiples may lead to our beginning to understand when and whether two- or three-dimensional models were used in ancient foundries.

\section{Notes}

1. Vatican Museo Pio Clementino: Richter, 1970, p. 225-226.

2. Olympia, inv. B 145 and B 4315 ; Athens, National Archaeological Museum, inv. 7582; New York, Metropolitan Museum of Art, inv. 1972.118.54.

3 . They are the largest of the griffins in

U. Jantzen's group of monumental griffins:

U. Jantzen 1955, p. 65-66.

4. Mattusch, 1990.

5. See, for example, Kyrieleis, 1990.

6 . For a summary of the arguments, see Mattusch, 1988, p. 200-208.

7. Formigli, 1985, Formigli, 2003, p. $65-70$.

8. Brinkmann, 2016.

9. For discussion, see Mattusch, 2014, p. 135-139. For the analyses, I am grateful to Gerhard Eggert, Staatliche Akademie der Bildende Kunst Stuttgart (Mahdia herm: XRF, AAS, NAA), and to Jerry Podany, J. Paul Getty Museum (Getty herm: EMPA) 10. See Mattusch, 1996, 139-140. More recently Power and Pathos 2015, 288-293, especially Sophie Descamps-Lequime 288-
290; Badoud, 2010, 137-138; Badoud, 2015; and Badoud in this volume; Mille and Descamps-Lequime forthcoming. 11. See Pappalardo, 2015, 329-330, 338.

12. The differences in measurements range from $1 \mathrm{~mm}$ to $3.5 \mathrm{~cm}$, with the Pompeii Apollo being consistently the larger of the two. Positions also vary slightly. I thank Jens M. Daehner and Kenneth Lapatin for taking the measurements for me. 253

13. See Mattusch and Lie, 2005, p. 249-

14. Naples, National Archaeological Museum, inv. no. 5616.

15. Rome, Villa Albani, H. without base $96 \mathrm{~cm}$. Bol 1989, p. 188-191.

16. Cleveland Museum of Art inv. 2004.30. H 1.5 m. Compare Bennett, 2013.

17. Richter, 1970, 225-226; Moreno, 1987, p. 133-140; Moreno, 1995, p. 196-205.

18. Vienna, Kunsthistorisches Museum. H 1.91 m. Oberleitner, 1978, p. 103-104. Power and Pathos, 272-273.

19. For this question, Ridgway, 2015 Barr-Sharrar, 2016, and Ridgway, 2016. 20. Kimbell Art Museum AP 2000.03. H. with base $51 \mathrm{~cm}$; weight $16.6 \mathrm{~kg}$. First recorded in the collection of Bernardo Nani (1712-1761), Venice. See https://www. kimbellart.org/collection-object/headathlete-apoxyomenos. Power and Pathos 276 277-281.

Bibliography

Badoud N., 2010, « Une famille de bronziers originaire de Tyr ", Zeitschrift für Papyrologie und Epigraphik 172, 125-143.

Badoud N., 2015, Le temps de Rhodes. Une chronologie des inscriptions de la cité fondée sur l'étude de ses institutions. Vestigia 63, Beck, Munich.

Barr-Sharrar, 2016, Response to Ridgway, BMCR.brynmawr.edu/2016/2016-0229.

Bennett M., 2013, Praxiteles: The Cleveland Apollo, Cleveland.

Bol, 1989, Forschungen zur Villa Albani: Katalog der antiken Bildwerke I, ed. P. C. Bol, Berlin.

Brinkmann V. 2016, Athen: Triumph der Bilder, Frankfurt.

Exhib. Florence-Los Angeles-Washington, 
2015: Power and Pathos. Bronze Sculpture of the Hellenistic World [Exposition, Florence, Palazzo Strozzi, 14 March-21 June 2015; Los Angeles, J. Paul Getty Museum, 28 July-1 November 2015; Washington D.C., National Gallery of Art, 6 December 2015-20 March 2016, Daehner J. M., Lapatin K. (eds.)], Giunti Editore, Fondazione Palazzo Strozzi, J. Paul Getty Trust.

Formigli E., 1985, "La tecnica di costruzione delle statue di Riace”, Due Bronzi da Riace: Rinvenimento, restauro, analisi ed ipotesi di interpretazione, vol. 1, Bollettino d'Arte serie speciale 3, Rome, p. 107-142.

Formigli E., 2003, "I Bronzi di Riace sono stati costruiti con la tecnica diretta della cera persa?" I Bronzi di Riace: Restauro come conoscenza I, Vaccaro A. M. and De Palma G. (eds), Rome, p. 65-70. Jantzen U., 1955, Griechische Greifenkessel, Berlin.

Kyrieleis H., 1990, "Samos and Some Aspects of Archaic Greek Bronze Casting", Small Bronze Sculpture from the Ancient World, ed. M. True and J. Podany, Malibu, p. 15-30.

Mattusch C., 1988, Greek Bronze Statuary: From the Beginnings Through the Fifth Century BC, Ithaca.

Mattusch C., 1990, "A Trio of Griffins from Olympia”, Hesperia 59, 1990, p. 549-560.

Mattusch C., 1996, Classical Bronzes: The Art and Craft of Greek and Roman Statuary, Ithaca.

Mattusch C. and Lie H., 2005, The Villa dei Papiri at Herculaneum: Life and Afterlife of a Sculpture Collection, Los Angeles.

Mattusch C., 2014, Enduring Bronze: Ancient Art, Modern Views, Los Angeles 2014.

Mille B., Descamps-Lequime S., forthcoming, "A Technological Re-Examination of the Piombino Apollo, in Lapatin, K., Daehner, J. (eds.), 19th International Congress on Ancient Bronzes, 13-17 October 2015
Los Angeles, Getty Trust.

Moreno P., 1987, Vita e arte di Lisippo, Milan.

Moreno P., 1995, Lisippo: L'Arte e la fortuna, Milan

Oberleitner W. et al., 1978, Funde aus Ephesos und Samothrake, Katalog der Antikensammlung II, Vienna.

Pappalardo U., 2015, "I bronzi", Caio Giulio Polibio: Storie di un cittadino pompeiano, ed. V. C. Morelli et al., Salerno.

Richter G., 1970, The Sculpture and Sculptors of the Greeks, 4th ed., New Haven.

Ridgway B. Sismondo, 2015, review of Power and Pathos: Bronze Sculpture of the Hellenistic World, in bmcr.brynmawr. edu/2015/2015-09-02.html

Ridgway B. Sismondo, 2016, response to Barr-Sharrar in BMCR.brynmawr. edu/2016/2016-02-47. 